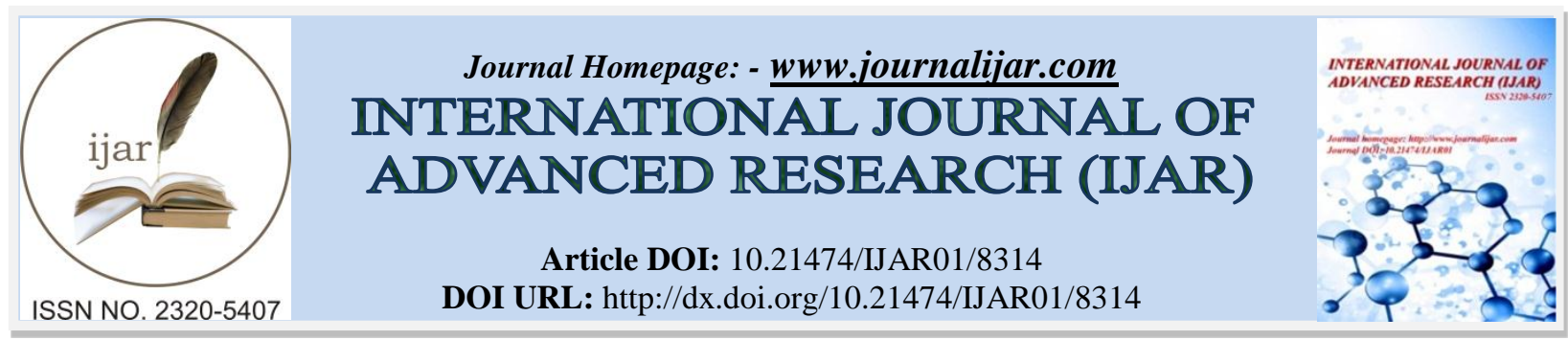

RESEARCH ARTICLE

\title{
WOMEN'S VOICES IN THE IMAGES AND SHADOWS OF PATRIARCHY.
}

Rea Mae Estrella ${ }^{1}$, Andrewgene Teologo ${ }^{2}$, Michael Bauga ${ }^{2}$, and Reynaldo B. Inocian ${ }^{2}$.

1. Social Studies State Scholars, College of Teacher Education, Cebu Normal University, Cebu City, Philippines, 6000.

2. Director, Institute for Research in Innovative Instructional Delivery (IRIID), Cebu Normal University, Cebu City, Philippines, 6000.

\section{Manuscript Info}

\section{Manuscript History}

Received: 04 November 2018

Final Accepted: 06 December 2018

Published: January 2019

Keywords:

Images, shadows, patriarchy, socialreproductive roles, child-rearing, traditional.

\begin{abstract}
This study described the images and shadows of patriarchy through the voices of women, how they were portrayed, and treated in the patriarchal society. A qualitative descriptive design was used. Interviews were conducted to generate data. These data were analyzed using descriptive thematic analysis. The key informants to this study were married women with children living in one family. These women dutifully did their responsibilities as wives and mothers, depicting the typical Cebuano household. Under the patriarchal society, their voices are limited: managing the family is their strength; emotional attachment to the family is their weakness; expanding their social reproductive roles is their opportunities; and domestic-related issues such as infirmed and/or loss of family members and child expectancy pressure plus the eventual child-rearing are their threats. The Cebuano women in the rural areas are dominantly traditional since they still ascribe to motherhood as part of their gender identity. Their images and shadows are reflections of a systemic culture of partriarchy.
\end{abstract}

Copy Right, IJAR, 2018,. All rights reserved.

\section{Introduction:-}

Driven with the culture of feminism, Cebuano women have a trouble standing shoulder to shoulder with men in the society. If the precolonial period prevailed, Cebuano women did not feel such disparity. From that period, Western intervention did not have changed the standing of women with men, until feminist theories have taken popularity in the early part of the $20^{\text {th }}$ century. Today, patriarchy circulates in the very veins of Cebuano society. At home, a family is well-regarded by its neighbors if a male lead is present. For the purpose of unofficial identification such as for small town gossips and drinking sessions, people are mentioned by pairing of the spouses' names (i.e. JuanaJuan). Attaching the two names reflects how much the Cebuano society inseparably sees couples in name and in action. The spouse takes much credit for the behavior of the other and since it is the woman who is usually left at home, her community sees her and puts her to work harder for her family.

Corresponding Author:-Reynaldo B. Inocian.

Address:-Institute For Research In Innovative Instructional Delivery (Iriid), Cebu Normal University. 
In most churches in Cebu, women hold their silence during the mass or the service as protocoled by their religion. Preachers are predominantly men and women can only have a role when it is out of bounds of the mass or service proper. In school, the influx of female teachers does not discredit male teachers to ahve given higher regard allowing them to take more leadership roles, more tasks, and more school activities. On the streets, PUJ drivers are seldom women. Men also dominate in the managerial field, farming, machineries, and in other professions.

The Cebuano society shows fear to have favored a family with a male central lead. This brings out a stable sense of leadership in the family. Patriarchs are regarded to have strong and firm command under their roof. The necessity of having men in control is for firmer decision making, disciplined family regulation, and financial security. All of these constitute to bring the ideal family household anchored on the presence of a man in the house. Matriarchal families, on the other hand, are seen to be a product of an unfortunate disaster whether it is brought about by the sudden passing of the husband or raising a child out of wedlock. These sorts of families are perceived to be fragile. When the feminine gender is in control, it is viewed to have: an indecisive rule, a loose family control, and doubtful financial capabilities. Even when they are not leading families of their own and find themselves alongside with their husbands, women still have their fair share of struggles. Situating themselves in a family with a prominent male lead, women take on the subordinate role. They are given less credit in all fronts for the arduous tasks they dochild rearing, doing laudry, marketing, and home-making. They are always on a timetable whenever they are with friends because their domestic duties wait for them. They are constantly at fault whenever their husbands exhibit socially deviant behaviors such as vices and illegal activities.

This study is conceived in order to surface the microcosmic scenario of patriarchy blending in plain sight in Cebuano families. This is done to provide a contextualized viewpoint of women experiencing firsthand the adamant presence of patriarchy. Conversely, this study would give women the avenue to express their grievances, perspectives, and expectations that modern Cebuano society fails to take notice to. In doing so, this would explore the extent of the hold of patriarchy in Cebuano homes and why it has continued to persist long after the colonization period. On a macro scale, this study would ride on the feministic wave happening in the world today.

\section{The Thesis Statement}

This study described the images and shadows of patriarchy through the voices of women, how they were portrayed, and treated in the patriarchal society.

\section{Review of Related Literature}

Patriarchy in the family means that within the social unit, the father or the eldest male exercises absolute control. This does not only mean rising above the ladies of the family but with the younger male members as well. In an extensive view of control, patriarchy has a major hold over culture, sexuality, economy, and the state (Gupta, 2018). But for the purposes of this study, the context of patriarchy within the family is elaborated.

\section{Portrait of Women in Patriarchal Society}

Traditional societies have drawn their line when it comes to the roles of wives and husbands. Husbands are expected to sweat out for livelihood whereas women are in charge in domestic management such as cooking, doing laundry, washing the dishes, etc. (Medina, 2001). Role specification according to gender was rooted in the pre-industrial period of human history. This was when society mainly consisted of hunters and gatherers. Men were skillful hunters while women were expected to look for the welfare of the household and the children while their husbands went away (Medina, 2001). There are distinctive patterns of authority observed. Traced back to Biblical times, patriarchal form vested the control of the family to the eldest male typically the husband or the father. Another form which was deemed unusual and unreal was the matriarchal family. Contrary to its name, matriarchal families still cling to the male relative which is usually the brother. The term matriarchal took sense in the family in a matrilocal residence, wherein the wife's family absorbed her authority and control (Medina, 2001).

During adolescence, the concepts of masculinity and femininity are well engraved to the context of young individuals. Being modest and well-mannered is mastered among young ladies while being outgoing and chivalrous is to be demonstrated among young men. As quoted by Mendez, et al. in Medina (2001), girls during their childhood lured to play with dolls for them to look forward for their role in the greater picture of the society. Women were subjected to family experiences on a daily basis (Medina, 2001). 
Men could directly have their way when it comes to matters of money and assets whereas women would still need the concession of their husbands to do the same. Eviota in Chant \& McIlwaine (1995) suggested that while women are regarded to be household managers, there are still reservations for such role. Women give such great importance to the egos of the masculine gender. Women took their places at the sidelines in order to set the stage for their husbands whether at home or at the face of public affairs (Chant \& McIlwaine, 1995). There is such a construct in sexuality wherein the males were regarded to be "predator" and the women possessed the "prey" character in the form of submissiveness (Estrada-Claudio, 2012).

Patriarchy runs deep for the ladies working in sugar farms in Negros. The women of Negros dutifully do their roles as wives and mothers. They have stamped to their identities that men should be well-attended to. Growing up in a community wherein women see that their mothers do more roles than their fathers, they inherit these role orientations in managing their own families. With the gendered roles finely set to let the woman carry the duties of family reproduction, patriarchy stood atop of traditional rural families (Dungo, 2005). In Sorsogon, the dominant position of men is highly revered within the bounds of marriage. Both the husband and wife recognized the role of husbands as "breadwinners" to keep harmony with their roles as "homemakers" (Dungo, 2015).

\section{Voices of Women in the Modern Society}

The Family Code of the Philippines, under Articles 69 to 71, mandates husband and wife shall fix the family domicile; the spouses are jointly responsible for the support of the family; the management of the household shall be the right and the duty of both spouses (RA 8533, 1987). This is based on the notion that the mutual agreement of two individuals could bring out the best in the family. New circumstances may play into action but a family prevailed to be the society's most basic institution, that is universal (Medina, 2001). To Aleta, Silva \& Eleazar in Chant \& McIlwaine (1995), "Changes may take place in the Philippine society but an expectation that the husband is a breadwinner and a wife as the homemaker is still constant." The common take is that masculinity is popularly perceived of being a provider, a conqueror of women, and a father of the family. Femininity on the polar end is painted to be inferior, dependent on men for their welfare, and a sexual object. Literature reveals that the ideal woman in Philippine society is one who appears relatively weaker and lower compared to a man.

For women's status to be assessed meaningfully, it would be assessed in a way relative to Filipino men (Chant \& McIlwaine (1995). Men's attitudes towards partners who earn to balance the finances in households are not coherently welcomed. Their actions show that they resist in lending a hand to women's unfinished chores when they take their leave for work. Women can count on their older children to get household chores done when they come home from school than their husbands. Women in most cases strike a negotiation with their husbands but would strive to do household chores beyond the line of their agreement. Negotiations of working women would also extend to their work superiors as they would explain their situation to them.

Husbands would also feel wary of wives' absence conducting tensions between the two of them (Dungo, 2005). Though most men recognize the need of their wives to take on jobs, they also expect the best of them in childrearing. Household chores are still dominantly held under women's jurisdiction. The probability of arising conflicts would always be at door's edge because certain standards and family ideologies prevail in the house atmosphere. Men see women indifferently as the latter do both domestic and economic duties than the former. This created a series of commotions between the two not only as husbands to wives and vice versa but also in the over-all household management as well (Dungo, 2005). Husbands gain more free time when not fulfilling their breadwinning roles. They could involve themselves in more "manly" indulgences exemplified as drinking and socializing with friends except when they do household repairs or gardening. Sevilla in Medina (2001) explained that husbands of working women understand the gravity of labor their wives do, and so they lend both their hands together in helping the household chores.

Women are still regarded to be subordinates of their husbands. Though this is a common Filipino scenario, women nowadays tend to create a restructuring of this old orientation. They build "spaces" in doing the said goal. In so doing as men would insist, women would assert. Wives of the recent age are now more expressive. Depending on the situation, they could be more patient and accommodating and show anger and disappointment (Dungo, 2005). There is a growing trend in Western societies wherein both husband and wife would choose from the wide array of gender role responsibilities for the ones they would less likely do. Knox in Medina (2001) revealed that a wider table of options is being set out for couples, in order to meet needs and situations. The concept of househusband is 
relatively new in the Philippines, but it is a concept slowly gaining recognition. This is cause by several factors like the: rising population of women in the labor force, job retrenchment, and others.

A separate study concluded that men who are more educated are more likely to help in household activities (Medina, 2001). Husbands who attended elementary education dedicate an average of 0.9 hours a day to household chores. Husbands who reach secondary education give 2.2 hours to chores (Medina, 2001). Husbands who finished tertiary education devote 2.5 hours (Medina, 2001). To Medina, the latter population of husbands allocates more time to their families, the same study has shown that they prefer more babysitting, household repairing, and water fetching than any other chores. Educated men may be more willing to help but traditional view complicates them. The traditional view still holds that men should be breadwinners and anything else would make them henpecked husbands (Medina, 2001). The househusband's role is largely true in urban areas. Wives in the urban areas worked like their husbands; they did necessary adjustment in household management (Medina, 2001). Younger and educated husbands follow a more liberal pattern. They involved themselves more in the household to accommodate their wife's roles. As men's involvement increased, the overload of work in women decreased (in Pleck as quoted by Medina, 2001). Plunging into this new orientation may take a few drawbacks. With the husbands' more involvement in child-rearing, the wife slowly loses her previously notable domain.

Conjugal power may be held by either spouse or the power structure may be geared to be more equal in nature (Medina, 2001). The economic odds may not always be on the favor of the husbands. So if the window of opportunities presents itself to the wives, the family dynamics shifts. The need to redefine masculinity and femininity in the household was imperative (Tadeo-Pingol, 2001). The dominant position in the household is held by the spouse with the symbol of modernity. Hutheesing in Tadeo-Pingol (2001) explained that men are held to have access to work in the modern sector but with the growing number of women in the work force, the wife and husband dynamics get tipsy. Power relations put women to take high paying jobs while men assume to take multiple roles.

\section{Strengths of Women}

It is true that wives are hailed as "purse strings" of the household. They also are the "co-managers" and "executioners of their husbands' wills" (Chant \& Mcllwaine, 1995). Regarded as a co-manager and treasurer, the Filipino wife dutifully does her role as a partner to her husband. In a study conducted by Castillo in 1993 quoted by Medina on thriving families in Metro Manila, it showed that $95 \%$ of houses recognize the need for a wife's monetary contribution while $33 \%$ of the overall incomes of these families rely on the wives' salary (Medina, 2001). Women of lower standing augmented their husbands for the family survival (Medina, 2001).

Physically demanding tasks are said to be given to the masculine gender for their inherent physical superiority while the feminine are biologically inclined for child bearing. Consequently, the attachment of women for child care and housekeeping remained apparent (Medina, 2001), that needed women' assertiveness to break the system of patriarchy (Dungo, 2005). Collaborating with other women compels women to challenge the domesticity of their gender and how much it benefits patriarchal value. A growing sense of autonomy among women brewed to reassert and compensate the preparation of the family budget. This air of independence fueled them to pursue their line of work (Dungo, 2005). Women manage both social reproduction duties and paid work and cannot use as an excuse to the existence of one for the other. Women are geared towards works of social reproduction or works that sustain families, communities, and societies. If the government was unable to provide basic services, women "by default" provide them without salary (Buenaventura, 2005).

\section{Weaknesses of Women}

Though women play significant roles in production, they are still referred as "invisible." National accounts regard them with no economic value as indicated by Human Development Report. This report showed that women are still not credited for a total of US\$ 11 Trillion (Buenaventura, 2005). To Amenegro-Etego in Buenaventura, "Women are caught in a position wherein their resources are withdrawn from them and are assigned to the most menial and difficult line of work" (Buenaventura, 2005). Various forms of discrimination violate women. These encompass women who are in the state of poverty, disabled, ethnic, Muslim, distanced settlers from the city, bisexual, lesbian, and transgender. The added societal expectations of women that involve more favor for men afflict them too. Women had scored a higher poverty incidence as compared to the rest of the Philippine population at 25.6\% in 2012 (Philippine Development Plan, 2017). 
Disordered eating can be commonly found on women who have striven for intellectual and professional improvement (Silverstein \& Perlick, 1995). Low levels of self-esteem, bugging weight concerns, and eating problems are more diagnosed to females than on males which bring about higher rates of depression of females than on males. Society's full-scale permission for men to achieve what they want makes them far susceptible to depression but the exact reverse treatment to women makes the latter vulnerable to it. This syndrome among wives shows indication of nausea, poor appetite, breathing difficulties, palpitations, and fatigue (Silverstein \& Perlick (1995). Society regards women who cannot bear children as failures. Hence, women who put career on top of their families are also placed in the same regard. Women are also faced by the responsibility of taking care of relatives who are infirmed. Women feel a deep sense of fulfillment if they could bear children. Not only had women viewed to think that way, but the society as well (Silverstein \& Perlick (1995)

\section{Opportunities of Women}

Gender was seen as a pivotal factor on the division of labor and resources (Dungo, 2005). Women met the society's expectation to produce their best for the society, despite their sex orientation (Buenaventura, 2005). Agoncillo \& Guerrero in Medina (2001) recalled that Filipino women who lived during the Spanish times did not have the egalitarian status than women had with men during pre-colonial times. But now, the colonial bondage is not anymore an issue, shouldn't this pre-colonial status be once more ascribed to them? Women's contribution to the economy captured both productive and reproductive spheres over the decades (Buenaventura, 2005). It is possible for women to be the main economic providers in the family. As rejoined, women empowerment exhibited $63 \%$ in garment enterprises in Bulacan because they owned the business (Tadeo-Pingol, 2007). Trade policies from the local to the global level must be included the concerns of women especially those who worked in the informal economy (Asia, 2005). Beginning at the most basic level, women change their lives in the spheres of their own, household, and community. They speak out to political discourse and practice working their way to mainstream themselves in governance. They are heading towards transformative politics which is more participatory, responsive, inclusive, and accountable. Women's collective perspectives about constructing a just, diverse, peaceful, and free society with all its elements co-existed together should have been aired out to the world (Report, 2005) to establish a difference.

\section{Threats of Women}

Women's jobs are directed toward the extension of their social reproductive roles such as nurses, secretaries, waitresses, salesladies, etc. whose wage is relatively lower than the managerial positions handled by men. Their social reproductive tasks were hard even if they took jobs of the same nature (Buenaventura, 2005). Aleta, Silva \& Eleazar in Chant \& McIlwaine (1995) elaborated that employers regard these women as 'secondary workers' because they are only seen to back up their husbands' wages. Lamb, Pleck \& Levine in Medina (2001) rejoined that sharing domestic responsibilities may be ideal for the working wife but it is at the expense of her bond with her children and managerial control at home. Incompatible aspirations versus frequent rush of emotional turmoil hinders women's path toward achievement. In most cases, women have to give up their careers while men remain resilient. A wife subconsciously blames her husband for her ascribed status and role expecations. Women's domestic problems reflect their gender roles as mothers, who became complacent to household chores; and society's expectatiosn imposed to them as women (Silverstein \& Perlick, 1995).

Most men were not open to the notion of working wives and questioned the growing absence of women in the household (Dungo, 2005). Pavia-Ticson in Chant \& McIlwaine (1995) considered men to have put a third of their time to help women in the household tasks. This is supported by Ward in Dungo (2005) that help from husbands in a little while faded away into an air of indifference and resistance. The home became a battleground for 'who-doeswhat' arguments (Dungo, 2005). Husbands of lower standing could hog over their patriarchal supremacy at home posing a threat to their wives' liberty (Tadeo-Pingol, 2001). There is a need to protect more to women who take action on job shifting. There are no established legal means to specify the welfare of balance for those women in the work sector. The greatest vulnerability is held in their pregnancy and maternity. Maternity leave is not adequate for the needs of women. In joining the labor force, women also realize they are taking the unwanted occurrence of gender wage gap, gender segregation, domestic violence, and sexual harassment. There should be a growing need to empower women and aid them on a nationwide scale their professional and personal life balance (Philippine Development Plan, 2017). 


\section{Research Methodology:- \\ Research Design}

This qualitative study utilized descriptive design. Descriptive design refers to the study of focus. This design anchors on the notion that practices could be changed and improved via observation, analysis, and description (Koh \& Owen, 2000). This study sought out how much deep seated patriarchy in Cebuano society affects household women.

\section{Research Key Informants}

The key informants of this study were married women with children. They dutifully did their responsibilities as wives and mothers depicting a typical Cebuano household. They also came from different economic classes in the three selected cities of Cebu.

\section{Research Instruments}

An interview guide composed of unstructured questions was made, reproduced, and used in the interview of the key informants. The responses of the key informants were recorded; transcribed, clustered, and emerging patterns were used to generate the required themes.

\section{Research Locale}

The study was conducted in the three designated areas of Mandaue City, Talisay City, and the City of Naga in the province of Cebu.

\section{Inclusion and Exclusion Criteria}

Through a snow-ball sampling, the 30 key informants were selected based on these primary criteria: married with children and a husband who stayed in one dwelling; and resided in the chosen locale for more ten years. These 30 were also selected based on three representative economic samples of ten women from the lower economic strata; ten women from the middle income group and another ten from the higher economic income. Ladies who cohabited but were not married; and those who were married but not sired with children were excluded in the study.

\section{Data Analysis:-}

From the recorded interviews, these were transcribed. Emerging patterns were noted and themes were generated through a thematic analysis. Thematic analysis is a method that identifies, organizes, and gives patterns of meaning to the data in a systematic manner (Braun \& Clarke (2006). These themes were clustered into four categories according to the Strengths, Weaknesses, Opportunities, and Threats or the SWOT analysis.

\section{Ethical Considerations}

To ensure reliability on the part of the key informants, letters of intent were sought for permission to conduct an interview. These letters were approved and signified by the concern authorities. Along with it, a letter of informed consent was also handed out ensuring the security of their answers and anonymity of their identities. As reflected in the informed consent, the key informants were not coerced and their psychological safety was ensured. They were consulted on what available time they could spare in the interview. Gestures of appreciation were done after the interviews.

\section{Results and Discussion:-}

Themes on Strengths of a Woman

Responsibility in Family Orientation

It is said that mothers are the light of the household. With Filipino families closely knit upon each other even at the grassroots of Philippine society. The wives from the lower economic standing do understand this.

I find my strength in taking care of my family (KI-1). I deal with my kids hands on; I teach them all they need to learn so they would not stray away in life (KI-2). My husband is my strength (KI-20).

The wives have been taught that their role is attached to the house. They were trained to answer first to the call of domesticity (Dungo, 2005). They understand the role they play in raising children for the sake of their welfare. 


\section{Unquestionable Love, Care, and Support of the Family}

Similar with the orientation of the lower classes, the middle class women also treasure their family bonding.

My strength is in my family because they love and support me (KI-13). I always point out my rights as a mother and as a wife (KI-4). My strength is in my family because they love and support me (KI-13). Taking care of my family is my strength (KI-24).

The difference between the two testimonies: wives want to define the role they play on family relations, and the need to show their strength. A woman in the family asserted to concede to spread awareness on the need for women empowerment (Dungo, 2005).

\section{Planning Strategies for Family Centeredness and Bonding}

Women of higher economic standing not just want to uphold their entitlement as mothers but also to own the role by being the overall family planner.

I like to organize and plan around the house and about family activities (KI-18). I like to plan about my family's day and how I could make it nice (KI-25).

This rejoined planning as one way of effective household management that defined them as household "comanagers" (Chant \& McIlwaine, 1995).

\section{Themes on Weaknesses of Woman}

\section{Feeling Anxious when the Family Encounters Economic Problems}

Wives of the lower economic class have only one root problem they want to articulate and provide in a more stable income for their families.

I really feel this emptiness inside me whenever we do not have enough money and food because the family could really feel the struggle (KI-1). I am fearful whenever my husband is not around because he is at work then the children would get sick because I feel that is an inescapable situation (KI-2). I dread the day that I would not be able to provide the needs and wants of my family (KI-11). I am apprehensive when it comes to family problems (KI-20).

Wives are not afraid by the ability to attain scant resources for themselves for the family's money and food. They face these threats feeling helpless without the aid of their husbands and see that these could be overcome if their husbands were to be present by their side.

\section{Vulnerability to Walk-in Temptations}

I am fearful when couples give in to temptations (KI-19). I easily give in to the lure of gambling (KI-21).

Women of lesser economic income among families are more vulnerable to all sorts of temptations. This is because they have greater spare time as compared to those who are situated in the higher social ladder.

\section{The Angsts of Physical Infirmities}

When illnesses strike the husband and the children, the mother fears for their welfare and take appropriate actions.

I dread whenever a family member gets sick (KI-4, 22, 23). Sometimes it is just too overwhelming. For example when my child gets sick, despair takes over me and it feels like hoping and imploring to God's mercy to heal the child (KI-5).

Since wives are mothers who cannot deny the great pain they have experienced when they give birth. They are inclined to protect their family from illness and provide maximum comfort.

\section{Selflessness and Strong Faith of a Mother}

Beyond what is superficially seen by most in the society is that women also have their thoughts and resentments mixed in their motherly thinking. This is seen in the responses of the middle class women. 
My weakness is being stubborn at times when doing something without thinking clearly (KI-13). I gave up everything I had before for my family (KI-14). I get to spend time on praying to God for healing on my child's terrible sickness (KI-5).

Mothers also could come to the point of regretting something they have given up for the rest of their lives. They also admit that they are not perfect mothers but they strive to be better. They also become resilient on their faith along the way if they feel that demands of motherhood are too much.

\section{Sacrifice is the Backfire of Great Love for Families}

Suzanne Collins, world renowned young adult fiction writer, says that "the things we love the most hurt as the most." This has been recalled by those women in the higher class as they reveal what makes them weak.

I cannot take for granted on my family. I have always put their welfare above mine (KI-7). Whatever happens to my children would also have an amplified effect on me (KI-16).

What they draw strength upon can also be the source of their weakness. Women of the family prioritize their family rather than looking at her own betterment. The children who are the source of great joy could also be the source of great sadness, when untoward incident happens or whatever misfortunes.

\section{Compassion in the midst of Resource Allocation}

Women on the higher class are confused on how they should spend the money at hand.

I'm very compassionate to people especially the poor. I give them money (KI-18). I have a spending problem that is why I easily run out of budget (KI-25).

The two sides of the coin of resource allocation are presented. Sharing of resources to those people in need is noble virtue, making sure that there is still enough for the family to use. On the other side, spending issues that run out of budget remains the greatest challenge in financial literary.

\section{Themes on Opportunities of a Woman}

\section{The Pleasure of Cultivating Positive Family Relations in the Household}

Women of lower economic standing are geared towards ensuring positive relations in the household.

I consider taking care of my family with great love and honesty as an immense privilege (KI-1). I take pride in organizing the household by doing the laundry, putting the children to sleep, and overseeing the cleaning of the house (KI-2). Taking care of my children and husband gives me pleasure (KI-3).

Women regard it as a great opportunity to be confident enough in them to take care of their families. They do not just merely play their roles; but they add values to it. They view everyday household chores as main avenues in fulfilling their motherly roles.

\section{Fulfillment in Taking Social Reproductive Roles to help the Community}

Social Reproductive Roles defined the works that sustain families, communities, and societies (Buenaventura, 2005). These are the types of work that are typically ascribed to women because of their innate social relations skills. They take on these jobs to augment the salary of their husbands.

I was voted chairwoman in an environmental clean-up (KI-20). I was appointed to report whenever there would be rows in the neighborhood (KI-21).

Women have found fulfillment beyond their domain in the family. They take on these social reproductive roles as extensions of what they do in the family. Supervising the cleaning of the surroundings has a greater coverage than supervising the cleaning of the house. Being a reporter of verbally provoking parties is a mature way of being a peacemaker.

\section{Valuing Women's Role in the Family with Love and Contentment}

Women in the middle class keep themselves knitted to their families as well. 
I take each day as an opportunity to make more memories and be more loving and contented (KI-13). I am a mother and a wife in my family (KI-23). I take it seriously to love and protect my family (KI-4). I take each day as an opportunity to make more memories and be more loving and be contented (KI-13).

Women dedicate much of their time and effort to their families because they value them above all else. They have accepted this role and even anticipate it, ahead of time that all roads would eventually lead to this role.

\section{The Balance of Domestic Work and Career Advancement}

Women of the middle class would always show the need to rise for self-fulfillment and career advancement. Even if they genuinely care for the families they have; they also want something beyond of what is expected of them.

I want to pass the board examination to pursue teaching. In line with this, I also want all my children to excel in their studies (KI-5). I really look forward to my career advancement (KI-14). I am a Sunday school teacher for the children (KI-22). Even though I am a wife, I still want to work abroad (KI-24).

Socially reproductive professions are not just on the local level. These are formal jobs that compensate them in some way. They aspire to become teachers, because teaching is a step-up from being a teacher to their children in making for homework. Being a Sunday School Teacher in the Church gives me a sense of spiritual fulfillment. Career advancement also includes taking a bit higher than the domestic duty that is to work abroad.

\section{Wider Perspectives on Career Opportunities}

Women of the higher class see more avenues for self-development aside from striving daily as the best maternal figure.

I may be able to reach the highest peak of my career (KI-18). It is a great opportunity for me to have my own business (KI-7). As a woman, I see a lot of opportunities waiting for me for work, politics, and education (KI-17). I may be able to reach the highest peak of my career (KI-18).

Women of the higher class have wider perspectives when it comes to opportunities whether it's job-related, politics, or education. They embark on the great investment of doing business or even establishing one of their own. This is the efficient to balance challenging roles of being a mother and a career oriented. These women are career-driven who still want to work to the highest peak.

\section{Themes on Threats of a Woman}

\section{Fear and Anticipation about the Future, Family Security and Protection}

The greatest commitment of women among economically lower standing is their role towards their families. This is something they undertake very religiously so if these are disturbed, an air of devastation sweeps upon them.

I fear for the loss of my loved ones (KI-1). I fear being assaulted of my own husband (KI-3). I worry if my children would marry early (KI-10). I also worry whenever there are disputes in the neighborhood (KI-21).

The very existence of the family gives wives their itinerant activities so it is logical if they fear the very loss of the family's existence. As mothers, these women also anticipate the future of their children. They fear that because of the growing exposure of the younger population to concepts of romance and lust that they would seek after to early marriages. If chaos among neighbors occur, this strikes fear to the mother as she is on the lookout primarily to the peace of her family and secondly to the harmony of the neighborhood.

\section{Fear of Giving Birth and Death}

Life and death are the significant points of the circle of life. They are natural as they are formidable.

I fear on constant pregnancy and the increasing number of children in tha family because I have no one else to help me (KI-2). I fear death (KI-20).

Giving birth is a cause of great joy to families especially to Filipino families. However, if it is already an annual event then that happiness fades into disgust for not having anything else to do. Women of economically lower 
standing fear on constant pregnancies. Pregnancies are costly and hinder them from doing as much household chores they used to do. Pregnancies especially on a yearly basis mean another mouth to feed which may not have been the issue if they are able to provide. But for these women, the greatest threat of constant pregnancies is constantly standing at death's door worried about the other children they have left and their future without them. They fear that their other children may not be guided properly growing up the moment they leave them behind.

\section{The Fear of Being a Woman and a Mother}

Women in the middle class battle the attack on their femininity and suppressing the stereotype of being random in mood and thought. Like the women of economically lower standing, they also fear death.

I see it as a threat whenever my threats would be stepped on (KI-4). I don't see constant childbirth advantageous because it poses a threat to children's education (KI-5). I tend to be more aggressive and impulsive (KI-13).

Because they perceive an attack on their women's rights as a threat, women of middle class standing are more aware about their women's rights and when these are overstepped. They fear to increase the number of their children at the expense of the other children's chance of proper education and brighter future. Women had more aggressive and impulsive tendencies (Dungo, 2005).

\section{The Fear of being unwanted}

Women of middle standing glue their families together. They do not fear the health conditions but the emotional and economic impacts over the loss of someone in the family.

It really upsets me whenever my husband gets sick because aside that I worry for his well-being, I also get frantic as to where I would get resources for our daily needs (KI-22). It truly brings me great fear if I would lose anyone in my family (KI-23).

In a time of adversity, a woman cries first but she also takes action. She takes in the father's misery as well as the search of sustenance for the family, when her father is gone. She does not only feel crippled when her husband breaks but also the rest of the other members of the family.

\section{Fear in Fulfilling with Family Expectations}

In a patriarchal society like the Cebuano society, the responsibility of child-rearing rested upon the mother or other dominant female figure (Dungo, 2005).

Because I am the wife, there is a great pressure on me to give birth (KI-7). I tend to get nervous during child labor because there is a 50/50 chance on my survival and I further worry for the child (KI-17). I really could not sleep if any of my children get sick. I fear it immensely that is why I do all sorts of preventive measures (KI-25).

Women of higher economic standing face the pressure of whether or not they could bear a child. Women who failed to procreate are seen lowly by society (Silverstein \& Perlick, 1995). And if they could, they face the invitation of having one foot in death's door as they labor for a new life to begin. When the child is developing and growing, the mother would by all means evade the child from illnesses because her maternal instincts would have kicked her off by then. Her intuition towards ensuring the welfare of children makes women called more for domesticity.

\section{Conclusion:-}

Women, as one of the vulnerable sectors in human society, have different images and shadows in a deeply rooted sytem of patriarchy. Their economic social stratification paints a tapestry of strengths, weaknesses, opportunities, and threats based on their gender orientation. Their images portray a system of unbreakable patriarchy that no amount of education could easily break. These images are shown in the expectations of men, which remain visible among women to provide birth to children as men wish them to have. Their attachments to the house as a homemaker, their roles as manager and peace-maker in the family are shadows of women's angst, burden, anxiety, fear, temptations, anticipation of the future, and other challenges which they struggle in the context of poverty and the situation of being feminine. While they endure the traditionally oriented patriarchal treatment, shadows of masculine dependency remain unbreakable. 


\section{Recommendation:-}

In this fast paced world, the disparity between men and women should not be this great. Women should be able to acknowledge themselves as individuals full of potential not just being blind followers of life that has been laid out for them in a 'silver platter' by their families and by their gender orienation. This does not necessarily mean that they should neglect their ascribed duties at home. It only means that doors should never be closed for them because of their gender status and obligations. This gives them the drive to do better and choose right endeavor to be successful. Future studies are recommended to examine women's lenses that promote women empowerment in business, politics, and in education.

\section{References:}

1. Asia, H. S. (2005). Why Fair Trade, Not Free Trade for Women Workers in the Informal Economy. Review of Women's Studies, 208.

2. Braun, V. \& Clarke, V. (2006) Using thematic analysis in psychology, Qualitative Research in Psychology, 3:2, 77-101, DOI: 10.1191/1478088706qp063oa

3. Buenaventura, M. V. (2005). GATS and Privatization: Surfacing the Gender Dimensions. Review of Women's Studies, 175-198.

4. Chant, S., \& McIlwaine, C. (1995). Women of a Lesser Cost: Female Labour, Foreign Exchange, and Philippine Development. Quezon City: Ateneo de Manila University Press.

5. Dungo, N. G. (2005). Negotiating Patriarchy and Globalization: Dynamics of Women's Work in an Agricultural Economy. Review of Women's Studies, 41-66.

6. Estrada-Claudio, S. (2012). Amnesty International's Policy on Sexual and Reproductive Rights. Review of Women's Studies, 222-235.

7. Gupta, A. (2018). Four Walls of Patriarchy. New Delhi, India: Academia.com

8. Koh E.T., Owen W.L. (2000) Descriptive Research and Qualitative Research. In: Introduction to Nutrition and Health Research. Springer, Boston, MA

9. Medina, B. T. (2001). The Filipino Family. Diliman, Quezon City: The University of the Philippines Press.

10. Philippine Development Plan (2017-2022). Republic of the Philippines.

11. Report, P. N. (2005). Beijing +10 - Celebrating Gains, Facing New Challenges. Review of Women's Studies , $237-248$.

12. Republic Act No. 8533 (1987). The New Family Code of the Philippines. Retrieved from http://www.chanrobles.com/executiveorderno209.htm\#.W2GV8dUzbIU

13. Silverstein, B., \& Perlick, D. (1995). The Cost of Competence: Why Inequality Causes Depression, Eating Disorders, and Illness in Women. New York City: Oxford University Press, Inc.

14. Tadeo-Pingol, A. (2001). Remaking Masculinities: Identity, Power, and Gender Dynamics in Families with Migrant Wives and Househusbands. Quezon City: University Center of Women's Studies. 